\title{
Assessing the Threat of Nexus Between Organized Crime and Democratic Politics: Mapping the Factors
}

\author{
Catalina Uribe Burcher * \\ International IDEA, Sweden
}

\begin{abstract}
In recent years, increased attention from the media, the international community and policy makers has highlighted the destabilizing effects criminal networks have on the legitimacy of democratic politics, as well as the capacity of democratic systems to deliver basic services. Indeed, the Organization for Economic Co-operation and Development highlighted in 2014 how illicit financial flows drain the state from resources needed to provide basic services (OECD, 2014). While this problem affects not only developing and fragile states, these countries are particularly affected as this phenomenon tends to exacerbate inequality (Briscoe, Perdomo \& Uribe Burcher, 2014). Mapping the factors that make politics vulnerable to the influence of organized crime is a key element in the effort to implement adequate strategies to prevent and mitigate this phenomenon. This paper explores 21 threat factors identified, understood as some of the conditions that may contribute to the likelihood that political corruption linked to organized crime takes place. These threat factors underline institutional weaknesses-including those related to illicit political finance - and organized crime activities, which create opportunities for illicit networks to penetrate democratic political systems. The paper also discusses how these institutional weaknesses interrelate to specific criminal markets and networks. The paper draws from extensive desk research in 2015, which complements previous desk and field research on the same topic carried out in 2011-2014 in the Baltic States, Latin America and West Africa.
\end{abstract}

Keywords: organized crime, political corruption, illicit networks, state fragility, political finance

\section{Introduction}

Organized crime has become a security and governance threat to most countries in the world. It easily adapts to new environments and propagates its power, using dirty money as its weapon of choice (UNODC, 2010). In democratic political systems, alliances between organized crime and corrupt politicians and public officials erode the values and practice of democracy by systematically exploiting institutional weakness, affecting rule of law and distorting transparency in decision making (Kupferschmidt, 2009; Allum \& Siebert, 2003; Sung, 2004; Van Dijk, 2007; MacCoun \& Reuter, 2001; Bailey \& Godson, 2000; Paoli, Greenfield \& Reuter, 2009).

Catalina Uribe Burcher, Programme Officer, International IDEA, Sweden.

* Ackowledgement: Part of the research for this article was conducted in collaboration with Victoria Perotti. In addition, the paper author would like to extend her appreciation to Francesco Strazzari, Gerd Junne, Kimana Zulueta-Fülscher, Brechtje Kemp, Nathalie Ebead, Elin Falguera, Sam Jones and Helena Schwertheim, who provided feedback and expert advice on the analytical model and threat factors proposed in this paper. Views expressed in this publication do not necessarily represent the views of International IDEA, its Board or its Council members. 
The nexus between criminals and political elites includes a wide range of relations, from predatory to parasitic and even symbiotic (Lupsha, 1996; Cockayne \& Pfister, 2008, p. 18). This comprises both explicit and tacit agreements, mediated by money or influence, that may be forged directly or through intermediaries. Understanding the democratic vulnerabilities and criminal activities that contribute to forging and maintaining these linkages in a given context therefore enables governments and civil society organizations to mobilize resources and develop strategies to prevent and mitigate them more effectively.

Drawing from the notions provided by the UN Convention on Transnational Organized Crime-also known as the Palermo Convention (UN, 2000)-, for the purpose of this paper "organized crime" is considered as a broad range of illicit activities committed systematically and with continuity, by a group of three or more persons or by a network with clear division of tasks, to gain profit and increase power or political influence. Another important concept used throughout this paper is of the "factor". This is understood as a condition that contributes to the likelihood that a particular event will occur (Vogt \& Johnson, 2011, p. 137). It is important to note that "threat factor" analysis, according to this notion, does not consider the event's potential impact, i.e. the harm that the nexus between organized crime and politics generates. This would otherwise constitute a "risk analysis", which includes both its likelihood and impact (Albanese, 2001; World Economic Forum, 2015, p. 56; ECDC, 2011, p. 22), and it falls outside of the scope of this paper.

The concept of "democracy" is also used throughout this paper, taking the definition proposed by the International Institute for Democracy and Electoral Assistance (International IDEA) as a starting point. Under this notion, "democracy" is a form of government that may have diverse forms, but is always anchored under two basic principles: (a) popular control over public decision making and decision makers; and (b) equality of respect and a voice between citizens in the exercise of this control (International IDEA, 2008, p. 712). While organized crime can also forge alliances with political actors in non-democratic systems, the drivers and dynamics behind those relations are different from those operating in democratic systems. This paper looks specifically to the elements that can facilitate political corruption in relation to organized crime activities within democratic systems.

The analytical model proposed in this paper emerged as a result of International IDEA's protecting Politics project that since 2011 has been looking at the global challenges that transnational organized crime poses to democratic system (International IDEA, 2016b). Under this project, the paper author conducted extensive desk research in 2015 regarding the factors that may contribute to forging or maintaining alliances between organized crime networks and political actors. This desk research complemented previous International IDEA desk and field research on the same topic carried out in 2011-2014 in the Baltic States, Latin America and West Africa (Villaveces-Izquierdo \& Uribe Burcher, 2013; Briscoe, Perdomo \& Uribe Burcher, 2014; Aning \& Edu-Afful, 2013a, 2013b). This paper condenses this research under a series of 21 factors. While not exhaustive, these factors highlight (a) democratic weaknesses; and (b) organized crime activities that in some cases have facilitated the interlinkages between illicit networks and political actors. For each factor the paper provides a brief description and two examples.

It is worth mentioning that International IDEA is using this analytical model and the factors proposed in this paper to design an assessment tool to map and monitor the threat of nexus between organized crime and democratic politics. As of June 2016 the tool is undergoing piloting in Peru by the National Electoral Tribunal, partly using the analytical model described in this paper. The tool will be launched after two more pilots in 2018. 


\section{Factors}

The analytical model proposed in this paper clusters the potential enabling factors behind the crime-politics nexus under two dimensions: (a) democratic vulnerabilities, and (b) organized crime activities. This structure draws on a political economy analysis that looks at the incentives behind the crime-politics nexus from two perspectives: political actors as "suppliers" and "recipients" of benefits to and from organized crime activities, respectively; and organized crime networks as "suppliers" and "recipients" of benefits to and from political actors, respectively. Accordingly, the model focuses, on the one hand, on the democratic vulnerabilities that create opportunities to provide and receive those benefits. On the other hand, the model looks at the main organized crime activities involved in providing and receiving those benefits.
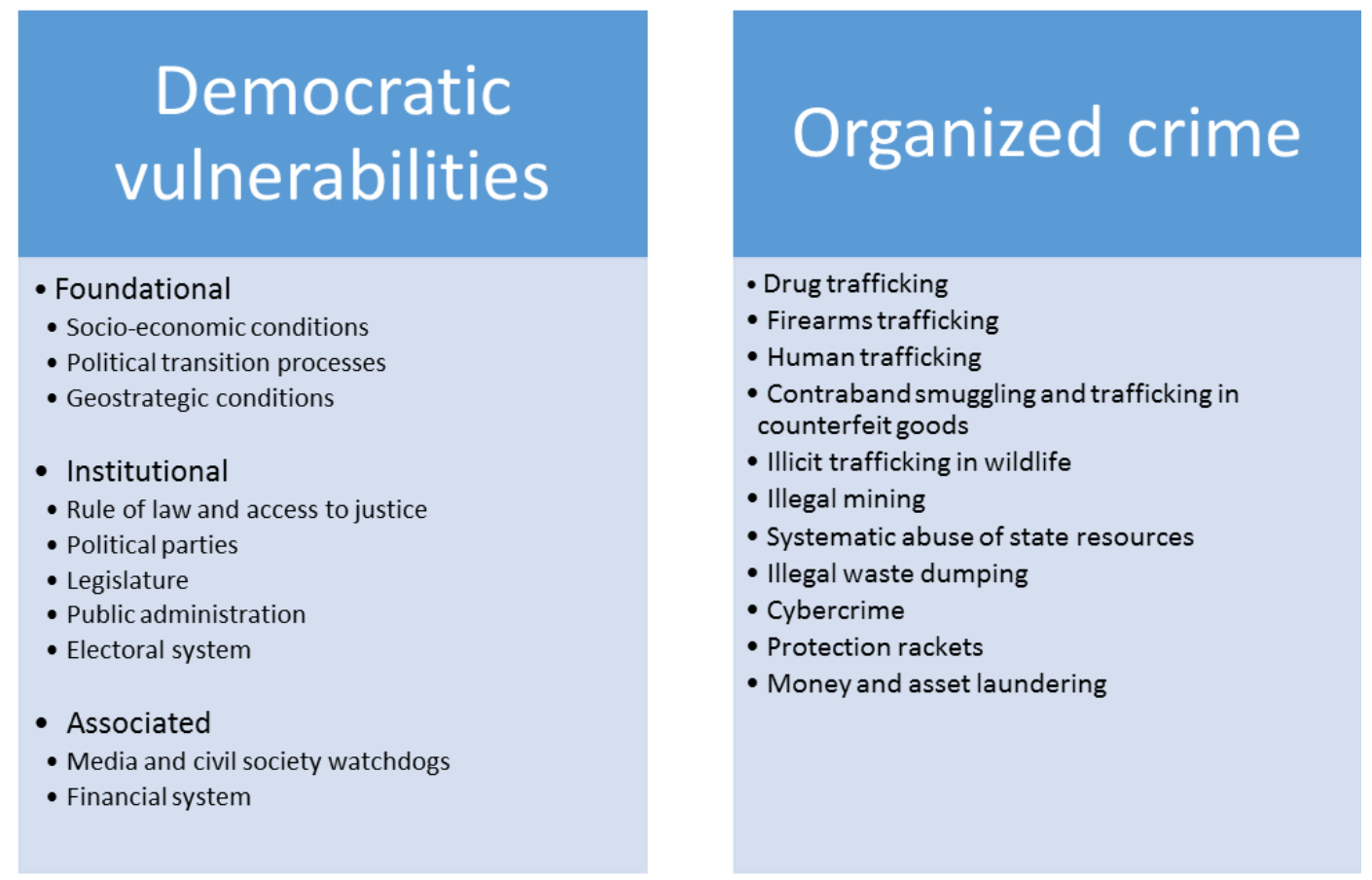

Figure1. The potential enabling factors behind the crime-politics nexus under two dimensions.

\section{Democratic Vulnerabilities}

This analytical model suggests a series of factors related to democratic weaknesses, understood as certain conditions of democratic governance that may create opportunities to forge and maintain alliances with organized crime. These factors build on the notion of democracy proposed by International IDEA as described above, which is grounded on four analytical democratic pillars: (a) citizenship, law and rights; (b) representative and accountable government; (c) civil society and popular participation; and (d) democracy beyond the state (International IDEA, 2008, p. 712). These pillars are used to distil those factors of democratic practice that are particularly vulnerable to the presence of organized crime under a graduated system that includes foundational, institutional and associated factors. Foundational factors are those that refer to the wider context (e.g. socio-economic conditions); institutional factors are those that look at the processes and actors directly and officially involved in democratic life (e.g. political parties); and associated factors are those looking at other institutions and systems that have a stake and impact in democratic life (e.g. the financial 
system).

\section{Foundational Factors: Socio-economic Conditions}

For the purpose of this paper and the analytical model it suggests, socio-economic conditions include the wealth of a country, the distribution of national income and how public revenues are invested in the overall structure of the state (Buscaglia \& Dijk, 2003, p. 14). In particular, poverty and unemployment, as well as social and economic inequalities create vulnerabilities across the sectors of the population affected by these conditions, making them easy targets for human traffickers or people smugglers. Also, these conditions create incentives for individuals to engage in criminal activities as sources of income since legal alternatives are often absent or less lucrative (Kruijt, 2011; World Bank, 2011; GI, 2015). Moreover, when the state fails to provide essential services-due to inefficiency or corruption-the communities affected may become further marginalized, creating opportunities for organized crime to fill the vacuum. These services ultimately render these networks with tolerance - and sometimes even support-from local populations (Buscaglia \& Dijk, 2003; Felbab-Brown, 2012), making it easier for organized crime to forge alliances with political actors (Briscoe, Perdomo \& Uribe Burcher, 2014).

The example of Brazil is telling in this regard. The relationship between drug traffickers and the favelas' residents exposes the complexities in the relations between criminals and local marginalized populations, fuelled by the state's inability to provide basic services. Indeed, in these favelas:

Drug factions have become a recognized socio-political force... Their power has been accepted by community populations due to fear and a lack of alternatives. Faction dominance has been based on historically existent structures of social control and protection that were developed into a system of 'forced reciprocity' maintained by a double tactic employed by drug traffickers: supportive coercion and repressive violence. (Dowdney, 2003, p. 52)

Guatemala is also a case in point. There, the crime network controlled by Juan Ortiz alias "Chamalé" in the Malacatán municipality took advantage of the continued absence of state structures to smuggle gasoline, food and other goods, and traffic people, drugs and arms. This alternative power structure positioned the network as the de facto state, to the extent that in the aftermath of natural disasters, it was often this network that provided early relief to the population. In turn, they enjoyed the collaboration of the local population to protect, for example, their illegal airports. This, among other conditions, made it easier for these criminals to build strategic alliances with political actors as these illicit activities became normalized and social controls were lax (Dardón \& Calderón, 2014, pp. 211-221).

\section{Political Transition Processes}

Political transitions, such as on-going conflict, peace agreements, disarmament, demobilization and reintegration processes, security sector reform initiatives, and constitutional reforms can create instability. This often renders organized criminal with significant territorial control, market opportunities and, most importantly, new avenues to forge alliances with political elites or reinforce them. Moreover, this positions criminals as important brokers in the new power structures resulting from these changing dynamics (Locke, 2012; Anderson, 1997, p. 44).

For example, in Sierra Leone drug trafficking rings took advantage of the country's instability and challenges in controlling its airspace and coastline during and after the 1991-2002 civil war. Groups managed to corrupt high-level government officials and secure trading routs. The case involving Sierra Leone's Minister of Transportation Ibrahim Kemoh Sesay and his brother Ahmed illustrates this. Apparently, the brothers were 
involved in mobilizing 703 kilos of cocaine in an airplane coming from Venezuela with fake Red Cross symbols, which authorities later seized (Aning 2010, p. 6). Similarly, the north of Mali has struggled from protracted instability, in that case partly fuelled by the separatist ambitions of the Tuaregs, widespread poverty and marginalization. This resulted in systemic corruption at all levels, fostering a myriad of illicit activities with the direct involvement of state officials (Reitano \& Shaw, 2015, p. v).

\section{Geostrategic Conditions}

A country's location, neighbours and resources can facilitate transnational organized crime. In particular, market globalization, the country's proximity to strategic crime routs, and the state's inability to control its borders and ports might create opportunities for external actors to use political corruption and advance their business interests within the country (Albanese, 2001). Likewise, the country's resources and its geography can facilitate certain types of crime. Timber and logging in the Amazon, for example, is one of the key drivers of deforestation in the region, and between $60 \%$ and $80 \%$ of this is believed to be illegal (Greenpeace, 2005). Moreover, localities surrounded by heavy forests or steep mountains result attractive for drug production and mineral and extraction given their physical isolation.

Lastly, a country's language connection to other countries or regions can also facilitate crime operations. For instance, Latin American networks operating across the region enjoy flexibility given the region's common language. Similarly, diaspora communities involved in crime can use language connections with their home countries to facilitate their businesses, while language barriers in their host countries help them avoid law enforcement operations as authorities cannot easily deploy intelligence operations to track them down. Benin is a case in point. Women are trafficked "to Belgium, France and Germany, predominantly for the purpose of sexual exploitation" (UNODC, 2006, p. 11); the existing relations between traffickers in Benin with diaspora communities in Europe facilitate the trade, with language as one of the enabling factors given the connections between the people involved along the trafficking route. Also, corruption among government officials through the trafficking rout starting in West Africa - particularly within criminal justice agencies - is a key ingredient for this crime as state officials are believed to facilitate false documents and launder money (UNODC, 2006, pp. 16, 24, 27, 57).

\section{Institutional: Rule of Law and Access to Justice}

The concept of rule of law, for the purpose of this paper, draws from the idea that the state should adhere to the law, govern through the law and ensure equality of all citizens before the law (Bleiker \& Krupanski, 2012). The judiciary and the security sectors are central to that concept. The judiciary involves, among others, the system of courts and tribunals at different levels, mixed control agencies and prisons (Calhoun, 2002). Corruption and reduced independence of the judiciary, which can take many forms, such as the de facto sale of favourable decisions by courts, selective or false investigations and prosecutions and abuse of substantive judicial discretion (Karklins, 2005; Sung, 2004) may increase impunity and, subsequently, create opportunities for public officials to engage with organized crime (Kruijt, 2011; Briscoe, Perdomo \& Uribe Burcher, 2014; Dijk, 2008). Linkages with the security sector, mainly the armed forces and the police, also provide organized crime networks with valuable information on cases under investigation (Kruijt, 2011). More broadly, weak institutional mechanisms to ensure safety in a territory often allow organized crime to fill the vacuum by providing their own protection rackets (Kruijt, 2011).

In Mexico, for instance, organized crime networks' involvement in the judicial system and security forces 
has impaired the state's capacity to provide public safety and order (Kenny \& Serrano, 2012). This is a problem faced by many other countries as well; a comparative study of 59 countries, including Mexico but also Colombia, Indonesia, Jordan, Turkey, Brazil and Ukraine underscored how democratic avenues to fight organized crime are seriously undermined when there is corruption in the judiciary (Sung, 2004, p. 29).

\section{Political Parties}

These organizations amalgamate people with common political ideas in order to, among other activities, mobilize citizens, participate in elections and inform public policy (Kemp, 2013, p. 24). Opportunities for organized crime to collude with political parties arises when the latter lack sufficient transparency and internal democracy mechanisms to regulate and oversee their finances and scrutinize their members and candidates (Villaveces-Izquierdo \& Uribe Burcher, 2013; Briscoe \& Goff, 2016a). A striking example took place in Argentina during the 1999 presidential election. Money from the Juarez Mexican cartel allegedly reached the campaign of candidate Eduardo Duhalde through a complicated international scheme, involving real estate investment in Argentinian assets by the cartel. Apparently one of the main contributing factors for this scheme was the lack of rules that limited anonymous contributions or required candidates and parties to report on donations (Ferreira Rubio, 2013, p. 32). A similar situation occurred in Mozambique. Mohamed Bachir Suleman, who is in the US Department of the Treasury's Foreign Drug Kingpin list for allege drug operations in Europe, is believed to have given millions of dollars to the ruling FRELIMO party in Mozambique. Local investigations have failed to connect him to the drug business, further sparking allegations of political corruption to protect him from prosecution (Kavanagh, 2013, p. 37).

\section{Legislature}

The legislature is part of the state's branch responsible for drafting legislation or other regulations at the national and local levels. The main benefit for organized crime in colluding with political actors is usually avoiding prosecution and law enforcement operations; while this is not part of their direct mandate, legislators are usually powerful politicians with connections to law enforcement and the judiciary, making then important brokers for organized crime networks. Their power to enact and block legal provisions also makes them important allies for criminal networks as they can create or maintain a lax environment for their activities (Briscoe, Perdomo \& Uribe Burcher, 2014). Afghanistan's example is telling in this regard. In 2005, the then governor of Helmand, Sher Mohammed Akhundzada, was prosecuted after authorities seized opium in his property. In spite of this and further evidence linking him and other state officials to the drug trade, he later became Member of Parliament (Reuter, 2013, p. 105). Similarly, in Colombia the infamous "para-politics" scandal unveiled the connections between members of Congress and cocaine traffickers, chiefly how these politicians provided direct and indirect protection to these networks across the country (López Hernández, 2010).

\section{Public Administration}

This system involves the government bureaucratic structure. This is a key asset for organized crime (Plekhanov, 2003, pp. 73-75). Firstly, weak decentralization frameworks that lack appropriate checks and balances vis-à-vis national authorities allow organized criminals to easily target and partner up with local political entities. In turn, this may affect the provision of public services (Bardhan, 2002, p. 185; Rios Contreras 2012, p. 6; Perdomo \& Uribe Burcher, 2016). Secondly, a flawed public procurement system makes it easy for criminal networks to exploit public contracts to extract state revenue (Reitano \& Hunter, 2016). In Guyana, for 
example, so called "political gangs" have apparently used the state apparatus to nurture popular support by distributing posts across their informal networks of influence. Weak procurement and civil service regulations and enforcement have been identified as facilitating factors for these strong patronage linkages at the local level (Walker, 2013, pp. 199-213). Also, in Bosnia Herzegovina a scandal unveiled the linkages between a powerful businessman and cocaine networks from Panama in 2000. This person apparently avoided a police operation by receiving confidential information connected to some of the authorities in charge of the operation (Chêne, 2008, p. 2).

\section{Electoral System}

An electoral system encompasses the regulations to elect public officials (ACE, 2015). These processes play an important role in the capacity of organized crime to distort politics. Illicit party campaign financing, illegal voter registration, electoral slush funds, vote buying, voter intimidation and improper vote counting are some of practices observed across the electoral cycle which are sometimes linked to organized crime groups (Briscoe \& Goff 2016b). In the worst cases, members of organized crime syndicates have run for public office themselves (Briscoe, Perdomo \& Uribe Burcher, 2014). Current trends, such as highly competitive and costly elections, alongside the complexities of monitoring political spending, work as a catalyst for these nexus (Casas-Zamora, 2013; Falguera, Jones \& Ohman, 2014). Italy is a widely known example of this phenomenon. In that country, criminal organizations in the south used violence "from the date of nomination for political offices to the date of elections, to intimidate, physically harm, blackmail, or abuse a political stakeholder in seeking to influence directly or indirectly an electoral process... to make sure that their preferred candidates got elected" (Sberna, 2011, p. 1). Colombia is also telling in this regard. The 2015 local elections were marked by accusations of influence of armed groups and mafia networks over politics. While criminal influence over politics seemed to have diminished, with violence in particular decreasing considerable in relation to previous elections, illegal armed groups still apparently used the election to control areas along trafficking routes by becoming directly involved in political blocs or by channelling funds into campaigns (Gagne, 2015).

\section{Associated: Media and Civil Society Watchdogs}

Civil society organizations (CSOs) and investigative journalists have an important role in disclosing corruption cases involving organized crime and political elites. Websites such as the Organized Crime and Corruption Reporting Project, the Global Investigative Journalism Network, the International Consortium of Investigative Journalists, and the Committee to Protect Journalists (CPJ) continuously report on these dealings, raising awareness of the modus operandi of illicit networks, thus contributing to hindering the capacity they have to distort politics. Unfortunately, journalists and the media are not always widespread or capable - due to lack of resources or intimidation - to report on political corruption and organized crime activities. According to the CPJ (2015), "journalists have been attacked while reporting on collusion between crime figures and government officials, and they have been targeted while pursuing crime or corruption stories during times of both peace and war".

El Salvador provides an illustration. In that country, the news site "El Faro" has become a leading institution in disclosing corrupt linkages between gangs and politicians, and its journalists have been threatened as a consequence. Carlos Dada, one of its founders, and author of a report on the "Texis cartel", which revealed how that network connected local gangs, prominent businessmen and politicians, has been constantly threatened as a consequence (233 grados, 2012). A scandal in Latvia provides a similar example, albeit without 
the use of violence. Here, the so called "media capture" scandal unveiled a scheme whereby oligarchs with linkages to both criminal networks and high level officials colluded to become majority shareholders of the country's most prominent media outlet. Their apparent aim was to curb the ability of journalists to report on their corrupt dealings (Villaveces-Izquierdo \& Uribe Burcher, 2013, p. 20).

\section{Financial System}

A country's banks, funds and insurers, among others institutions, constitute its financial system, providing the platform for the country's economic transactions and investment (IMF, 2015). A weak financial system is prone to abuse by transnational criminals, something that further erodes "market integrity, quality, and competitiveness' and [uses] financial systems to move, conceal, and increase illicit funds" (National Security Council, 2015). In the US, the case of Semion Mogilevich is an interesting example of how some individuals and networks can manipulate such a complex financial system. Mogilevich was accused in 2003 of "fraud, racketeering, and money laundering..., with involvement in a sophisticated securities fraud and money-laundering scheme, in which they allegedly used a Pennsylvania company... to defraud investors of more than [USD] 150 million" (The White House, 2012, p. 323). In contrast, Libya provides a striking example of a fragile financial system also prone to abuse by illicit networks. After the revolution that removed Muammar Qaddafi in 2011, organized crime activities and political corruption have been on the rise, particularly around the county's south. This is largely due to the region's economy, which is highly reliant on hand-in-cash transactions which fall outside the radar of the authorities (Shaw \& Mangan, 2014).

\section{Organized Crime}

These factors correspond to some of the main trafficking markets and enabling activities currently associated with organized crime as it affects democratic politics. Accordingly, they are the priority areas of the United Nations Office on Drugs and Crime (UNODC, 2015), which is the criteria used for their selection.

\section{Drug Trafficking}

This global trade involves the production, manufacturing, distribution and sale of substances that are subject to drug prohibition laws (UNODC, 1961; UN, 1971; UN, 1988, Art. 3.1 and 3.2). Numerous networks dedicated to this activity seek a nexus to political actors in order to gain protection from prosecution, free movement of their products and avenues to conceal their profits, among other benefits (Soberón Garrido, 1997). Given the scale of the drug trafficking business, which according to UNODC (2010) accounts for the largest crime activity in terms of profits, the corrupting capacity of these networks creates a governance threat for democratic institutions in the places they operate (Durán Martínez, 2007). In Mexico, for example, the forced disappearance of 43 students in the municipality of Iguala in 2014 unveiled a complicated chain of corruption all the way up to the local Mayor, who had developed linkages to drug traffickers. These linkages permeated many institutions within the state apparatus, including the police and other authorities who worked alongside or sometimes even together with gangsters (Grillo, 2014). Similarly, Afghanistan struggles with the challenge of opium. Currently leading in global production according to its estimated volume, the profits this market generates are largely laundered through corruption. Evidence suggests that drug traffickers have managed to occupy important positions within the government, establishing patronage networks across the country (Goodman \& Sutton, 2015). 


\section{Firearms Trafficking}

This type of trafficking involves the unauthorized "import, export, acquisition, sale, delivery, movement or transfer of firearms, their parts and components and ammunition" across internal or state borders (UN, 2001). The term "trafficking" can also be used to designate the "intentional diversion of [firearms] from legal to illegal commerce" without involving the movement of items across a physical border (Bricknell, 2012, p. 1). Besides profiting from their illegal trafficking, organized crime networks use firearms to protect their own illicit activities (Davis, Hirst, \& Mariani, 2001). Reports suggest that the "transfer of SALW from one country to another requires a network of both international traffickers and corrupt government officials" (Haken, 2011, p. 26). Indeed, political corruption is key to successfully conduct this trade given its linkages to matters of national security (Feinstein, Holden \& Pace, 2011). For instance, mafia groups have taken advantage of porous borders between the EU and Eastern European countries to operate a lucrative arms trade business (Davis, Hirst \& Mariani, 2001, p. 5). A similar example can be seen in Peru, where politicians linked to former president Fujimori's security chief Vladimiro Montesinos were allegedly involved in a complex network of arms smuggling. While the trade is transnational by nature, corruption at the national and local level was necessary in order to secure the transactions (Transparency International, 2011, p. 22).

\section{Human Trafficking}

Usually defined as the recruitment, transportation or receipt of persons, this type of trafficking is characterized by the threat of force or other forms of coercion, abduction, fraud, deception and abuse of power, among others. Human trafficking aims to exploit people, such as through prostitution or other forms of sexual exploitation, forced labour or services, slavery, servitude or the removal of organs (UNODC, 2004: Art. 3, par. a). A crucial element to conduct these activities is political and other forms of public corruption. Indeed, "human traffickers bribe law enforcement, immigration, and judicial officials in both origin and destination countries" (Haken, 2011, p. 10). During the late 1990s and early 2000s Eastern Europe was considered one of the regions most affected by this phenomenon, as the main source of people trafficked around the world at the time (OSCE, 1999, p. 5). Corruption among police officers reportedly facilitated this trade by ignoring the problem or even being actively engaged in exploiting people, particularly women (UNODC, 2011, p. 11), and the problem went through to include politicians (UNODC, 2011, pp. 7-8). In South Eastern Europe in particular, "institutional corruption [was] a catalyst for producing an environment where transnational criminality [could] flourish. Without the help provided by corrupt law enforcement, consular officials, diplomats, and lawyers the traffic in human beings in the region would virtually cease to exist" (Ovidia Vreja, 2005, p. 55). Bangladesh is also a case in point. There, high-level criminal investigations unveiled the support provided by public officials and politicians to human trafficking networks; eight officials were prosecuted for these crimes between 2004 and 2006 (Holmes, 2009, p. 88).

\section{Contraband Smuggling and Trafficking in Counterfeit Goods}

While contraband smuggling in general refers to goods that have been imported or exported illegally, counterfeit goods in particular are those that have been produced, distributed and sold under a false trademark (INTA, 2015). Besides the economic harm associated with this trade, more pervasive side effects include systematic health hazards due to counterfeit medicines. Corruption of politicians and public officials rank high among the driving forces behind these activities (IRACM, 2015). Nigeria provides one of the most ominous examples of how these networks operate. Until 2001 the country lead the world's counterfeit drug market. This 
situation was largely associated to systemic corruption of public officials and politicians, who allowed these networks to target manufacturers and gain access to the medicines market (Raufu, 2006). The EU and neighbouring Eastern countries also provide a telling example in relation to the illegal cigarette trade. The economic exchange between border regions - particularly in small towns - has maintained a cigarette market controlled and facilitated by corrupt customs authorities with ties to local politicians (Center for the Study of Democracy, 2010, pp. 16-17; Villaveces-Izquierdo \& Uribe Burcher, 2013).

\section{Illicit Trafficking in Wildlife}

This illegal trade of animals and plants can take place within a country's own borders or internationally (Traffic, 2015). Poaching of tigers and elephants, and the illegal timber trade in particular are lucrative businesses that threaten environmental sustainability in the countries where the animals and plants are exploited (WWF, 2015). Corruption, chiefly among high-level public officials and politicians, is one of the main driving forces behind this trade. Indeed, it facilitates inter alia issuing licenses and certificates, reducing oversight of patrol and customs officers, diverting investigations conducted by the police and prosecutors, manipulating court decisions, and ensuring easy routs for money laundering (Martin, 2013). Some regions are particularly affected by this trade, such as East Africa, especially Uganda, Congo and Sudan. In those countries, armed forces have been accused of involvement in the illegal ivory trade, becoming part of the chain all the way up to political elites that have benefited from the exploitation of elephants (Lawson \& Vines, 2014, p. 9; Corruption Watch, 2015). Similarly, in East Asia and the Pacific, particularly the Solomon Islands, high-level corruption "plays a central role in the supply of illegal wood-based products" (UNODC, 2013, p. viii). These networks require political support, in the case of the Solomon Island involving even cabinet ministers, to avoid law enforcement efforts to identify illicit timber that is often concealed among otherwise licit timber cargo. This corruptive trickle-down effect reaches primarily the border controls by land, sea and air, as well as authorities dealing with the documentation required to export legal timber (UNODC, 2013, pp. 88, 92).

\section{Illegal Mining}

This type of mining involves the "absence of land rights, mining license, exploration or mineral transportation permit or of any document that could legitimate the on-going operations" (Dozolme, 2015). With the rise of the international demand of minerals, this crime has become an environmental hazard because of its correlated deforestation and use of toxic substances like mercury (Hayman, 2013). Corruption among state officials facilitates this business. Avoiding prosecution and obtaining information regarding upcoming law enforcement operations are among the primary services public officials provide to these illicit networks (Uribe Burcher, 2014, pp. 151-154). In India, for example, numerous scandals have revealed the large extent to which this activity is conducted with the apparent support of some government officials. Indeed, in 2013 the government was criticised for terminating an investigation involving, among others, public officials. Most importantly, two former congress chief ministers were accused of involvement in and corruption in relation to illegal mining (The Guardian, 2013). The case of Indonesia - the world's lead exporter of tin —is also telling. Reports of massive illegal mining revealed how corruption was used to maintain a lucrative international illegal network all the way to Singapore and Malaysia. Police officers have been accused of colliding with illicit miners in order to halt investigations and protect criminals (Rusmana \& Sadmoko, 2015).

\section{Systematic Abuse of State Resources}

State resources should be enjoyed by citizens at large. However, authorities that manage these resources 
can abuse their power for their own benefit. When conducted in an organized and systemic way, it can become an organized criminal enterprise in itself (Reitano \& Hunter, 2016). Involvement of politicians and state officials is an intrinsic element of these crimes. This includes procurement misuse (Anti-Corruption Coalition Uganda, 2013), subsidy fraud schemes (Perdomo \& Uribe Burche, 2016), and trade-related fraud, such as customs fraud, value added tax (VAT) schemes (Rtvat, 2013), and abuse of carbon trade benefits (Interpol, 2013). As an example, in Kenya the government subsidised exports of gold in the 1990s, paying exporters in Kenyan Shillings (Sh) 35\% over their foreign currency earnings. It was later found that the gold was smuggled from the Congo. A corruption system supposedly comprising a number of government officials profited as a result, costing the country the equivalent of more than $10 \%$ of its annual Gross Domestic Product (GDP) (BBC, 2004a, 2004b; Wallis \& White, 2003). Similarly, in India the Superintendent of Customs was allegedly involved in a system of fraudulent claims for export incentives. The network reportedly procured fake import-export code licences and availed Indian Rupee (Rs) 25 core drawback - an incentive offered to boost exports where the incidence of tax and duty paid was reimbursed. Exports were declared as garments but were found to be rags. Their value was then apparently inflated to claim higher drawback (Singh, 2006).

\section{Illegal Waste Dumping}

This crime is committed when waste larger than litter is deposited against existing regulations, creating hazardous consequences for the environment, particularly when it involves toxic substances (EIA, 2008). This crime exploits mostly weak enforcement of environmental regulations across the countries involved in the trade. Public sector corruption is therefore the key ingredient to carry it out, especially during the process of licensing disposal facilities, issuing the export notification and authorising the export, among others (Martini, 2012). In Italy, for instance, Ndrangheta - a crime network operating in the southern region of Calabria - has been involved in waste dumping, including radioactive substances. These operations involved governmental officials and politicians in Italy and other countries affected by the scheme, such as Somalia (Squires, 2009). A similar situation, albeit in a smaller scale and with milder consequences, has also taken place in Northern Ireland in relation to fuel laundering — whereby marker dyes are removed from red and green diesel for further selling, producing waste as a result. The waste is typically disposed of in industrial bulk containers. Criminals, supported by corrupt officials, are involved in illegal waste collection and the provision of skips to illegal landfillingand burning of the waste. They usually charge the legal going rate to collect and transport waste and then dispose of it illegally, pocketing the profits (The Irish Times, 2015; Belfast Telegraph, 2015).

\section{Cybercrime}

A fast expanding activity, cybercrime relates to various forms of crime committed over electronic communications, networks and information systems (Edelbacher, Kratcoski \& Dobovsek, 2015, p. 27). These can take many forms, including identity fraud (e.g. credit card detail theft), technical and commercial espionage, and extortion. Organized crime may be involved in cybercrime either as a criminal objective in itself, or as a means to facilitate other crimes (Eurojust, 2014). According to the 2015 Global Risk report (Wold Economic Forum, 2015), cyberattacks "remain among the most likely high-impact risks", ranking ten in the index. Most concerning is the political use of cyberattacks. Indeed, politically motivated hacking is an increasingly used tool for some governments and political forces to advance their personal interests. Also, some national intelligence agencies are increasingly involved in a grey area of cooperation with international hackers, some of which are involved in crime networks (Grabosky, 2009). For instance, in South Africa corruption has been 
linked to the expansion of cybercrimes, seriously weakening the national security infrastructure as organized crime networks increasingly use these weapons for their activities. "Corruption-fuelled cyber-crime has resulted in insiders giving cyber-criminals access to critical information, as these insiders can easily bypass the security systems that organisations would have put in place" (Corruption Watch, 2014). Morocco is another example. There, a number of public officials were accused of creating a network to systematically spy on journalists. One scandal revealed what appeared to be spyware used against a citizen media project which was critical of the government, originating in the midst of the Arab Spring in 2011. The officials reportedly implanted a so-called Trojan malware to "take screenshots, intercept e-mail, record Skype chats, and covertly capture data using a computer's microphone and webcam, all while bypassing virus detection" (Gallagher, 2012; OCCRP, 2015).

\section{Protection Rackets}

The archetypical activity of organized crime, protection rackets are a form of extortion, most commonly found in gang-controlled urban environments. These rackets collect payment for protection from other criminal groups, and oftentimes from the group offering the protection in the first place (Volkov, 2002, p. 140). Interestingly, the connection between protection rackets and police authorities is most visible. Indeed, the police can sometimes create alternative power structures or para-states, with a tacit understanding that citizens — often local businesses — need to pay the authorities to receive special protection (Hirschfeld, 2015, p. 14).

The case of Indonesia is telling in this respect. The collapse of President Suharto's centralised authoritarian regime in 1998 led to social violence and coercion by gangsters, criminals and "violent entrepreneurs". To consolidate their position in this power-vacuum, many groups pledged loyalty to "political parties, business interests, organisations based around ethnic or religious identity” (Wilson, 2015, p. 21). Most specifically, in slums such as Bandung, a new type of racketeering leader emerged, where local strongmen derived political capital from their ability to organise street workers and mediate between the slum and the state, building their authority on economic protection rather than violent coercion (Barker, 2009, p. 72). For instance, in the run up to the 2014 Presidential election, the influence of local "preman" groups-protection rackets in the post-New Order Indonesia - was demonstrated as groups pledge their support for various presidential campaigns. Notoriously, the Forum Ormas Bersatu - a coalition of groups including the Pemuda Pancasila that has 3 million members in the Java region alone and is infamous for its intimidation for cash and political gain-officially pledged its support for the Gerindra political party (Tibke, 2014). Another example, although less widespread and entrenched than in Indonesia, has been reported among Australian police authorities in the Gold Coast. Some officers have been accused by the state's Crime and Corruption Commission of turning a blind eye over an organized crime protection racket that supposedly generated over 200 million Australian Dollars (Willacy \& Solomons, 2015).

\section{Money and Asset Laundering}

This crime enables criminal networks to conceal the illegal origins of money and assets, thus integrating them into the legal economy, often using shell companies and brokers (Interpol, 2015) and abusing loopholes and vulnerabilities from within the international finance system. Indeed, those countries suffering from high levels of corruption and organized crime activities face a higher risk of money laundering (FATF, 2012, p. 63). Politicians and so-called politically exposed persons (PEPs), i.e. individuals with prominent public functions, 
such as heads of state or government, senior politicians and senior government, judicial or military officials, and important political party officials (FATF, 2012, 112-113), pose a special risk. They have the capacity to circumvent traditional law enforcement and anti-corruption instruments targeting money laundering (FATF, 2013, p. 3).

The case involving Pierre Falcone in Angola provides a good illustration of how poor PEP controls have allowed proceeds from crime to be laundered, in that case in the US. A well-known illegal arms dealer with close connections to former Angolan President Jose Eduardo dos Santos, Falcone repeatedly abused his status and connections with the government in Angola to avoid oversight, holding numerous accounts at Bank of America to launder money through shell companies, later moving the money across a global network of accounts (United States Senate, 2010, p. 243). Similarly, in the UK various investigations have disclosed how banks based in London were systematically used to launder the proceeds of crime and corruption. In 2008, for example, a student based in London managed to open an account in a London-based bank with around 1 million Great Britain Pounds from a foreign politician and businessman who was his relative. The politician faced charges of "large-scale misappropriation of state funds and a court order freezing his assets worldwide", in spite of which "there was no indication... that the bank had identified this relevant adverse information and no evidence of annual reviews being conducted on this account" (LexisNexis, 2011, p. 10).

\section{Conclusions}

The analytical model proposed in this paper presents a list of factors that identify some democratic institutions and processes whose weaknesses, in combination with the presence of organized crime networks, may contribute to forging and maintaining corrupt criminal-political ties. While not exhaustive, this list provides a guidance to help prioritize efforts to prevent and mitigate those interlinkages. The model clusters these factors under "democratic vulnerabilities" and "organized crime activities". The first dimension on democratic vulnerabilities is classified under foundational (those referred to the wider context); institutional (those looking at the processes and actors directly and officially involved in democratic life); and associated (those considering other institutions and systems that have a stake and impact in democratic life).

Foundational factors include socio-economic conditions, political transition processes, and geostrategic conditions. These factors may increase the incentives for organized crime to engage with political and state actors. For example, high levels of inequality and failed public service delivery have been associated in some cases with tolerance towards the alliances between criminals and state actors. Increased political tensions related to transition processes, in turn, have been linked to increased opportunities to generate linkages with new power holders. Similarly, a country's resources, ports, borders with strategic trafficking routs, and linguistic linkages with foreign communities in key illicit markets may attract organized crime networks, which then need to turn to public sector corruption to advance or protect their interests.

Likewise, institutional factors may increase the threat of political corruption linked to organized crime. These include rule of law and access to justice - particularly the judiciary and the security sector-, political parties, the legislature, the public administration, and the electoral system. Systematic weaknesses in these areas may increase the vulnerability of political systems vis-à-vis criminal interests. For instance, impunity associated to a flawed rule of law and a lack of independent justice system may allow organized crime to operate at large. Also, political parties with unregulated and uncontrolled finances or incapable to screen their candidates may become vehicles for money laundering and for candidates associated with illicit networks to 
run for public office. This, together with a weak electoral system with lax controls over campaign financing, can be used by organized crime to secure strategic alliances with elected officials. Among those, members of the legislature may play an important role as power brokers for organized crime networks, given their capacity to promote or disrupt policy initiatives that may affect the interests of organized crime groups. Similarly, controlling or influencing the public administration in general, and the public procurement system in particular, is key for organized crime, mostly at the local level where they may easily exert control.

Finally, the democratic vulnerabilities described in this paper include a set of associated factors. These are the media and civil society watchdogs, and the financial system. Journalists and civil society engagement in fighting organized crime and political corruption are important when analysing the political system's resilience to criminal influence. These individuals and organizations act as important engines for public accountability, and are therefore often the target of intimidation. The country's financial system is also critical in creating the conditions to prevent or mitigate corruption linked to organized crime, but unfortunately this system in many countries suffers from protracted flaws in the oversight mechanisms related to the actions of people with political influence.

On the other side of the analytical model proposed in this paper are the activities in which organized crime networks are typically involved. These include drug trafficking, firearms trafficking, human trafficking, contraband smuggling and trafficking in counterfeit goods, wildlife trafficking, illegal mining, systematic abuse of state resources, illegal waste dumping, cybercrime, protection rackets, and money and asset laundering. For these criminal networks, connections with political actors are key for securing their interests. They provide them with protection from prosecution, free movement and money laundering mechanisms, among other benefits. The latter seems to be especially important as all these illicit groups require laundering money and assets to make use of the profits their businesses generate, and people with political connections hold a privileged position to avoid authorities' oversight and thus secure these schemes.

While all these networks use public sector corruption in one way or another, their scope and impact varies in some cases. Drug trafficking networks, for example, have a powerful economic muscle given the profitability of this market. This enhanced capacity to bribe makes them particularly threatening to the health of democratic institutions and processes. In the case of firearms trafficking, on the other hand, the connection to political corruption is also particularly pervasive as these illicit networks often touch upon interests and actors involved in national security that are in the realm of state and security actors. This is similar to the type of corruption that protection rackets often engage in, since security agencies and actors, most importantly police authorities, are at times associated or even part of these rackets. But probably the type of criminal activity where the nexus with state actors is most entrenched is in the systematic abuse of state resources, given that the role of politicians and officials is inherent in the activity itself.

Cybercrime, on the other hand, is arguably the illicit activity in which the involvement of political actors and usage of corruption is less prominent, given the disconnection between the medium in which the activity takes place and the actors involved. However, this paper has illustrated some cases in which cybercrime has been used for political purposes by state actors. As the potential for cybercrime appears to be increasing given the amount and importance of the activities conducted through information and communication technologies - including by state authorities and other democratic actors-, the threat that the political use of these crimes poses to the health of democracy makes it worth monitoring.

Furthermore, it is important to note the connexions between the two dimensions described in this paper (i.e. 
democratic weaknesses and presence of organized crime). Most organized crime networks seem to be able to benefit from weaknesses in most democratic institutions and processes-including the wider context and other correlated actors. However, depending on the case, the benefits between the two are more or less prominent. For example, based on the cases and situations discussed in this paper, there is no indication that cybercrime significantly exploits a country's poor socio-economic condition, transition processes, or weak political parties, electoral system or legislature. More important for cybercriminals seems to be the weakness among oversight actors, particularly the justice system, as well as the media and watchdog organizations.

This is starkly different from trafficking networks that require the movement of goods, resources, people or wildlife. In those cases, all democratic vulnerabilities described in this paper appear beneficial for their businesses, although in various degrees. For trafficking in wildlife and for illicit mining, for instance, the country's geostrategic conditions, specifically the availability of natural resources is a particularly important factor to determine whether organized crime networks, especially those dedicated to its production, exploitation and transfer, can operate. For human traffickers, on the other hand, language connections also appear to play a chief role in facilitating the business as it provides interconnectivity between criminals and victims, and language barriers provide isolation between criminals and authorities.

Protection rackets also significantly benefit from one particular democratic vulnerability, in that case weak security sector agencies. Indeed, the protection racket business is centred on exploiting insecurity in a specific territory. The same is true for firearms trafficking, since the business is largely based on corrupt relations with security actors. Also, for networks dedicated to the systematic abuse of state resources, a feeble public administration system, predominantly in the area of public procurement, is key to flourish. Lastly, and perhaps most clear of all, money and asset laundering is highly dependent on the weakness of the financial system. Further, albeit to a lesser degree, this illicit business also benefits from weak political parties and electoral systems, as they can be used as vehicles for laundering criminal proceeds.

\section{References}

ACE, Project Encyclopaedia: Electoral System. (2016). Retrieved May 30, 2016, from http://aceproject.org/ace-en/topics/es/default

Anderson, A. (1997). Organized crime, Mafia, and governments. In G. Fiorentini and S. Peltzman (Eds.), The economics of organized crime (pp. 33-60). Cambridge: Cambridge University Press.

Aning, K. (April 2010). Understanding the intersection of drugs, politics and crime in West Africa: An interpretive analysis. Policy Brief Series No. 6. Santiago de Chile: Global Consortium on Security Transformation.

Aning, K., \& Edu-Affu, F. (2013a). Legal and policy frameworks regulating the behavior of politicians and political parties-Sierra Leone. Stockholm: International IDEA.

Aning, K., \& Edu-Affu, F. (2013b). Legal and policy frameworks regulating the behavior of politicians and political parties-Ghana. Stockholm: International IDEA.

Anti-Corruption Coalition Uganda. (2013). The Black Monday Movement! Retrieved November 5, 2015, from http://accu.or.ug/dev/the-black-monday-movement/

Albanese, J. S. (2001). The prediction and control of organized crime: Risk assessment. Trends in Organized Crime, 6(3-4), 4-29.

Allum, F., \& Siebert, R. (2003). Organized crime: A threat to democracy? In F. Allum \& R. Siebert (Eds.), Organized crime and the challenge to democracy (pp. 1-24). London: Routledge.

Bailey, J., \& Godson, R. (2000). Crimen Organizado y Gobernalidad Democrática: México y la franja fronteriza [Organized Crime and Democratic Governance: Mexico and the border]. Mexico City: Grijalbo.

Bardhan, P. (2002). Decentralization of governance and development. Journal of Economic Perspectives, 16(4), $185-206$.

Barker, J. (1999). Negara Beling: Street-level authority in an Indonesian slum. In J. Barker \& G. van Klinken (Eds.), State of authority: The state in society in Indonesia (pp. 17-46). Cornell University Press. 
BBC. (2004a, February 14). Moi “ordered” Goldenberg payment. Retrieved November 5, 2015, from http://news.bbc.co.uk/2/hi/africa/3495689.stm

BBC. (2004b, May 20). Suspect "links" Moi to gold scam. Retrieved November 5, 2015 from http://news.bbc.co.uk/2/hi/africa/3733489.stm

Belfast Telegraph. (2015, March 17). Alarm at rise in fuel laundering. Retrieved November 5, 2015, from http://www.belfasttelegraph.co.uk/news/northern-ireland/alarm-at-rise-in-fuel-laundering-31073129.html

Bleiker, C., \& Krupanski, M. (2012). The rule of law and security sector reform: Conceptualizing a complex relationship. Geneva: DCAF.

Bricknell, S. (2012). Firearm trafficking and serious and organized crime gangs. AIC Reports, Research and Public Policy Series 116. Sydney: Australian Institute of Criminology.

Briscoe, I., \& Goff, D. (Forthcoming, 2016a). Weakening democracy: Organized crime and political parties. Stockholm: International IDEA and Clingendael Institute.

Briscoe, I., Perdomo, C., \& Uribe Burcher, C. (Eds.). (2014). Illicit networks and politics in Latin America. Stockholm: International IDEA.

Buscaglia, E., \& van Dijk, J. (December 2003). Controlling organized crime and corruption in the public sector. Forum on Crime and Society, 3(1-2), 3-34

Calhoun, C. (Ed.). (2002). Dictionary of the social sciences. Oxford: Oxford University Press.

Casas-Zamora, K. (Ed.). (2013). Dangerous liaisons: Organized crime and political finance in Latin America and beyond. Washington DC: The Brookings Institution.

Center for the Study of Democracy. (2010). Examining the Links between Organized Crime and Corruption. Sofia: European Commission.

Chêne, M. (2008). Organized crime and corruption. U4 Expert Answer. Oslo: U4.

Cockayne, J., \& Pfister, D. (2008). Peace operations and organized crime. Geneva Papers 2. New York: International Peace Institute IPI.

Committee to Protect Journalists (CPJ). (2015). Organized crime and corruption. Journalist Security Guide: Covering the News in a Dangerous and Changing World. New York: CPJ.

Corruption fuels cyber-crime in SA. (2014). Corruption Watch. Retrieved November 6, 2015, from http://www.corruptionwatch.org.za/corruption-fuels-cyber-crime-in-sa/

Corruption Watch. (2015). Corruption and the wildlife trade. Retrieved October 23, 2015, from http://www.corruptionwatch.org.za/corruption-and-the-wildlife-trade/

Dardón, J., \& Calderón, C. (2014). Case study on the network of Juan Alberto Ortiz Lopez, Alias "Chamalé" and "Brother Juanito". Illicit Networks and Politics in Latin America. Stockholm: International IDEA, Clingendael Institute and NIMD.

Davis, I., Hirst, C., \& Mariani, B. (2001). Organized crime, corruption and illicit arms trafficking in an Enlarged EU: Challenges and perspectives. Small Arms and Security in EU Associate Countries. London: Saferworld.

Dowdney, L. (2003). Children of the drug trade: A case study of children in organized armed violence in Rio de Janeiro. Rio de Janeiro: 7 Letras.

Dozolme, P. (2015). What is illegal mining? What you need to know about illegal mining. Retrieved October 23, 2015, from http://mining.about.com/od/OperationsManagement/a/What-Is-Illegal-Mining.htm

Durán Martínez, A. (2007). Organized crime, the state and democracy: The cases of Central America and the Caribbean. Rapporteur: Angélica Durán Martínez. New York: Fride.

Edelbacher, M., Kratcoski, P.C., \& Dobovsek, B. (2015). Corruption, fraud, organized crime, and the shadow economy: Advances in police theory and practice. Boca Raton: CRC Press.

Environmental Investigation Agency (EIA). (2008). Environmental Crime: A threat to our future. London: EIA.

Eurojust, Press release: Eurojust raises stakes in battle against cybercrime. (2014). The Hague: Eurojust.

European Centre for Disease Prevention and Control (ECDC). (2011). Operational guidance on rapid risk assessment methodology. Stockholm: ECDC.

Falguera, E., Jones, S., \& Ohman, M. (2014). Funding of political parties and election campaigns: A handbook on political finance. Stockholm: International IDEA.

Feinstein, A., Holden, P., \& Pace, B. (2011). Corruption and the arms trade: Sins of commission. SIPRI Yearbook 2011: Armaments, Disarmament and International Security. Stockholm: Stockholm International Peace Research Institute SIPRI.

Felbab-Brown, V. (2012). Aspiration and ambivalence: Strategies and realities of counterinsurgency and state-building in 
Afghanistan. Washington DC: Brookings Institution.

Ferreira Rubio, D. (2013). Argentina. In K. Casas-Zamora (Ed.), Dangerous liaisons: Organized crime and political finance in Latin America and beyond. Washington DC: Brookings Institution.

Financial Action Task Force (FATF). (2012). International standards on combating money laundering and the financing of terrorism and proliferation: The FAFT Recommendations. Paris: FATF.

Financial Action Task Force (FATF). (2013). FATF guidance: Politically exposed persons (recommendations 12 and 22). Paris: FATF.

Gagne, D. (2015, October 22). The evolution of criminal influence in Colombia's local elections. Insight Crime.

Gallagher, R. (2012, August 20). How government-grade spy Tech used a fake scandal to dupe journalists. Future Tense.

Global Initiative against Transnational Organized Crime (GI). (2015). Results-based approaches to organized crime and development: Input into the post-2015 development Agenda. Geneva: GI.

Goodman, M. B., \& Sutton, T. (2015, March 22). How to halt the Afghan drug trade: Follow the money. Newsweek.

Grabosky, P. (2009). Cyber crime: The global dimension. Journal of Law and Political Science, 36, 3-4, 73(411)-94(432)

Greenpeace. (2005). Logging in the Amazon. Retrieved November 6, 2015, from http://www.greenpeace.org/international/en/campaigns/forests/amazon/logging-in-the-amazon/

Grillo, I. (2014, October 9). Mexico's Deadly Narco-politics. The New York Times.

Haken, J. (2011). Transnational crime in the developing world. London: Global Financial Integrity.

Hayman, M. (Winter 2013). Illegal Mining. Americas Quarterly. New York: Americas Society and Council of the Americas.

Hirschfeld, K. (2015). Gangster states: Organized crime, kleptocracy and political collapse. New York: Palgrave Macmillan.

Holmes, L. (2009). Human trafficking and corruption: Triple victimization? In C. Friesendor (Ed.), Strategies against Human Trafficking: The role of the security sector. Geneva and Vienna: DCAF.

International Institute for Democracy and Electoral Assistance (International IDEA). (2016a). The electoral cycle. Stockholm: International IDEA. Retrieved June 7, 2016, from http://ecycle.idea.int/

International Institute for Democracy and Electoral Assistance (International IDEA). (2016b). Organized Crime and Threats to Democratic Politics. Stockholm: International IDEA. Retrieved June 27, 2016, from http://www.idea.int/conflict/

International Institute of Research against Counterfeit Medicines (IRACM). (2015). Problematic. Paris: IRACM Retrieved October 22, 2015 from http://www.iracm.com/en/fake-drugs/problematic/

International Monetary Fund (IMF). (2015). Financial System Soundness, Factsheet. Paris: IMF. Retrieved November 6, 2015, from http://www.imf.org/external/np/exr/facts/banking.htm

International Trademark Association (INTA). (2015). Protecting a trademark: Counterfeiting, factsheets. New York: INTA. Interpol. (2013). Guide to carbon trading crime. Lyon: Interpol, Environmental Crime Programme.

Money Laundering. (2015). Lyon: Interpol. Retrieved November 6, 2015, from http://www.interpol.int/Crime-areas/Financial-crime/Money-laundering

Karklins, R. (2005). The system made me do it: Corruption in postcommunist societies. New York: M. E. Sharpe,

Kavanagh, C. (Ed.). (2013). Getting smart and scaling up: Responding to the impact of organized crime on governance in developing countries. New York: New York University, Center for International Cooperation.

Kemp, B. (2013). Political party dialogue: A facilitator's guide. Stockholm: International IDEA, NIMD, The Oslo Centre.

Kenny, P., \& Serrano, M. (2012). Mexico's security failure: Collapse into criminal violence. New York: Routledge.

Kruijt, D. (2011). Drugs, democracy and security: The impact of organized crime on the political system of Latin America. The Hague: Netherlands Institute for Multiparty Democracy.

Kupferschmidt, D. (2009). Discussion paper on illicit political finance and state capture. Stockholm: International IDEA.

Lawson, K., \& Vines, A. (February 2014). Global impacts of the illegal wildlife trade: The costs of crime, insecurity and institutional Erosion. London: Chatham House, The Royal Institute of International Affairs.

Lexis Nexis. (2011). UK anti-money laundering (AML). White Paper. London: LexisNexis.

Locke, R. (2012). Organized crime, conflict and fragility: A new approach. New York: International Peace Institute IPI.

López Hernández, C. (Ed.). (2010). Y Refundaron la Patria: De cómo mafiosos y políticos reconfiguraron el Estado colombiano [And they rebuilt the country: On how mobsters and politicians reconfigured the Colombian state]. Bogota: Corporación Nuevo Arcoiris.

Lupsha, P.A. (1996). Transnational organized crime versus the nation-state. Transnational Organized Crime, 2(1), 21-48.

MacCoun, R. J., \& Reuter, P. (2001). Drug war heresies. Cambridge and New York: Cambridge University Press.

Martini, M. (2012). Environmental crime and corruption. Oslo: U4. Retrieved November 5, 2015, from 
http://www.u4.no/publications/environmental-crime-and-corruption/

Martin, M. (2013). Wildlife crime and corruption. U4 Expert Answer. Oslo: U4.

National Security Council. ((2015)). Strategy to combat transnational organized crime: Protect the financial system and strategic markets against transnational organized crime. Washington DC: National Security Council.

Organization for Economic Co-operation and Development (OECD). (2014). Illicit financial flows from developing countries: Measuring OECD Responses. Paris: OECD.

Organization for Security and Cooperation in Europe (OSCE). (1999). Trafficking in human beings: Implications for the OSCE . Warsaw: OSCE Office for Democratic Institutions and Human Rights ODIHR.

Organized Crime and Corruption Reporting Project (OCCRP). (July 8, 2015). Online surveillance firm "hacking team" gets hacked.

Ovidia Vreja, L. (Winter 2005). Human trafficking in South Eastern Europe. The Quarterly Journal, 4/4, 49-62

Paoli, L., Greenfield, V. A., \& Reuter, P. (2009). The world heroin market: Can supply be cut? New York: Oxford University Press.

Perdomo, C., \& Uribe Burcher, C. (2016 forthcoming). Weakening democracy: Organized crime local democracy. Stockholm: International IDEA and Global Initiative against Transnational Organized Crime.

Plekhanov, S. (2003). Organized crime, businesses and the state in post-communist Russia. In F. Allum \& R. Siebert (Eds.), Organized crime and the challenge to democracy. London: Routledge.

Protocol against the Smuggling of Migrants by Land, Sea and Air. (2004). Retrieved October 14, 2014, from https://www.unodc.org/documents/treaties/UNTOC/Publications/TOC\%20Convention/TOCebook-e.pdf Raufu, A. (2006). Nigeria leads fight against "killer" counterfeit drugs. Bulletin of the World Health Organization. Ibadan: WHO.

Reitano, T., \& Hunter, M. (2016 forthcoming). Weakening democracy: Organized crime and service delivery. Stockholm: International IDEA and Global Initiative against Transnational Organized Crime.

Reitano, T., \& Shaw, M. (2015). Fixing a fractured state? Breaking the cycles of crime, conflict and corruption in Mali and Sahel Geneva: Global Initiative against Transnational Organized Crime.

Reuter, C. (2013). Mirred in deception: Narcotics and politics in Afghanistan. In H. Böll-Stiftung and R. Shönenberg (Eds.), Transnational organized crime: Analyses of a global challenge to democracy. Bielefeld: Transcript Verlag.

Rios Contreras, V. (2012). How government structure encourages criminal violence: The causes of Mexico's drug war [dissertation]. Cambridge: Harvard University. Retrieved November 30, 2016, from http://scholar.harvard.edu/files/vrios/files/rios_phddissertation.pdf

Rtvat. (2013). The EU-wide problem of carousel fraud. Retrieved November 5, 2015, from http://www.rtvat.eu/european-vat-fraud.html

Rusmana, Y., \& Sadmoko, D. (2015, August 26). Corruption, death and tin mining. Bloomber Business.

Sberna, S. (2011). Electoral competition and criminal violence in Italy (1983-2003). ECPR Joint Session Conference, Workshop on Political Institutions and Conflict, St. Gallen, Retrieved October 23, 2015, from http://www.unige.ch/ses/spo/static/simonhug/ecpr/WORKSHOP_8_Sberna.pdf

Shaw, M., \& Mangan, F. (2014). Illicit trafficking and Libya's transition: Profits and losses. Washington DC: United States Institute of Peace USIP.

Singh, V.V. (2006, September 26). Customs official arrested for fraud. The Times of India.

Soberón Garrido, R. (1997). Corruption, drug trafficking and the armed forces. Amsterdam: The Transnational Institute TNI.

Squires, N. (2009, September 16). Mafia accused of sinking ship full of radioactive waste off Italy. The Telegraph.

Sung, H. (2004). Democracy and organized crime activities: Evidence from 59 countries. Security Journal, 7, 21-34

The Guardian. (2013, October 22). Indian illegal mining investigation ends without explanation.

The Irish Times. (2015, June 29). Authorities on "front foot" in tackling fuel-laundering.

The White House. (2012). Document No. 7: Strategy to combat transnational organized crime. In K. E. Boon, A. Huq and D. C Lovelace Jr. (Eds.), Terrorism: Commentary ion security documents, the changing nature of war (pp. 299-332). Oxford University Press.

Tibke, P. (2014). Hypocrisy laid bare in Indonesian election race. The Asian Correspondent, June 27, 2016, from https://asiancorrespondent.com/2014/06/hypocrisy-laid-bare-in-indonesia/

Traffic, Wildlife Trade: What is it? (2015). Cambridge: Traffic.

Transparency International. (2011). Organized crime, corruption, and the vulnerability of defence and security forces. London: TI UK Defense and Security Programme. 
United Nations. (1971). Convention on psychotropic substances. Retrieved October 14, 2014, from https://www.unodc.org/pdf/convention_1971_en.pdf

United Nations (UN). (1988). Convention against Illicit Traffic in Narcotics Drugs and Psychotropic Substances. Retrieved October 14, 2014, from https://www.unodc.org/pdf/convention_1988_en.pdf

United Nations (UN). (2000). Convention against Transnational Organized Crime and the Protocols Thereto. Retrieved October 14, 2014, from http://www.unodc.org/documents/treaties/UNTOC/Publications/TOC\%20Convention/TOCebook-e.pdf

United Nations (UN). (2001). Protocol against the illicit manufacturing of and trafficking in firearms, their parts and components and ammunition. Retrieved October 14, 2014, from https://treaties.un.org/doc/source/RecentTexts/18-12_c_E.pdf United Nations Office on Drugs and Crime (UNODC). (1961). Single convention on narcotic drugs. Retrieved October 14, 2014, from https://www.unodc.org/pdf/convention_1961_en.pdf

United Nations Office on Drugs and Crime (UNODC). Measures to Combat Trafficking in Human Beings in Benin, Nigeria and Togo. (September 2006). Vienna: UNODC. Retrieved November 6, 2015, from https://www.unodc.org/documents/human-trafficking/ht_research_report_nigeria.pdf

United Nations Office on Drugs and Crime (UNODC). (2010). The Globalization of Crime: A Transnational Organized Crime Threat Assessment. Vienna: UNODC.

United Nations Office on Drugs and Crime (UNODC). (2011). The role of Corruption in Trafficking in Persons, Issue Paper. Vienna: UNODC.

United Nations Office on Drugs and Crime (UNDOC). (2013). Transnational Organized Crime in East Asia and the Pacific: A Threat Assessment. Vienna: UNODC.

United States Senate, Keeping Foreign Corruption Out of the United States: Four case histories, Permanent Subcommittee on Investigations. (2010). Committee on Homeland Security and Governmental Affairs. Retrieved November 6, 2015, from http://www.u4.no/recommended-reading/keeping-foreign-corruption-out-of-the-united-states-four-case-stories-permanent-su bcommittee-on-investigations/

Uribe Burcher, C. (2014). Case study of the department of Puno. In I. Briscoe, C. Perdomo, \& C. Uribe Burcher (Eds.), Illicit Networks and Politics in Latin America. Stockholm: International IDEA, Clingendael Institute and NIMD.

Van Dijk, J. (2007). Mafia markers: Assessing organized crime and its impact upon societies. Trends in Organized Crime, 10/4 $39-56$

Villaveces-Izquierdo, S., \& Uribe Burcher, C. (2013). Illicit networks and politics in the Baltic States. Stockholm: International IDEA.

Vogt, W. P., \& Johnson, R. B. (2005). Dictionary of statistics and methodology (3rd ed.). USA: Sage publications.

Volkov, V. (2002). Violent entrepreneurs: The use of force in the making of Russian capitalism. Ithaca: Cornell University Press.

Walker, S. (2013). The impact of organized crime on governance: A desk study of Guyana. In K. Camino (Ed.), Getting smart and scaling up: Responding to the impact of organized crime on governance in developing countries. New York: New York University, Center for International Cooperation.

Wallis, W., \& White, D. (2003, December 15). Kenya: Officials, banks in \$1bn corruption probe. Corruption Watch.

Willacy, M., \& Solomons, M. (2015, May 26). Gold coast police investigated over protection racket around organised criminals. Australian Broadcasting Corporation.

Wilson, I. D. (2015). Politics of protection rackets in post-new order Indonesia: Coercive capital, authority and street politics. New York: Routledge.

World Bank, World Development Report 2011: Conflict, Security and Development (Washington DC: World Bank, 2011)

World Economic Forum. (2015). The global risks 2015 report (10th ed.). Geneva: World Economic Forum.

World Wildlife Fund (WWF). (2015). Overview. Threats: Illegal wildlife trade. Washington DC: WWF. Retrieved October 23, 2015, from http://www.worldwildlife.org/threats/illegal-wildlife-trade

233 grados, Amenazan a Periodistas Salvadoreños por Publicar Informes sobre el Crimen Organizado. (March 26, 2012). Salvadoran journalists receive threats for publishing reports on organized crime. 